\title{
Bahasa Etnik Pendatang di Ranah Pendidikan Kajian Sosiolinguistik Masyarakat Madura di Kota Surakarta
}

\section{Oleh: Kundharu Saddhono*)}

Abstrak: Penelitian ini merupakan kajian deskriptif kualitatif mengenai pemakaian bahasa etnik Madura di Surakarta pada ranah pendidikan. Data berupa wacana lisan dan dikumpulkan dengan teknik simak libat cakap (observasi partisipasi), teknik rekam, teknik catat, dan teknik wawancara mendalam (in-depth interview). Data dianalisis dengan pendekatan sosiolinguistik yang memperhitungkan konteks sosial berupa komponen tutur, yaitu penutur, mitra tutur, situasi tutur, tujuan tuturan, dan hal yang dituturkan. Hasil analisis dan pembahasan menunjukkan bahwa bahasa Indonesia mendominasi pada ranah pendidikan walaupun bahasa Madura dan bahasa Jawa digunakan. Fungsi bahasa Madura: kekeluargaan, keakraban, ungkapan perasaan, identitas etnik, kerahasiaan dan pemertahanan budaya; bahasa Jawa: kebiasaan, adaptasi dan keakraban; bahasa Indonesia: situasi formal, komunikasi antaretnik, sekadar bergengsi, pendidikan, dan pertemuan awal; bahasa campur: situasi nonformal, penegasan pesan, dan konsep baru. Kekhasan pemakaian bahasa meliputi kata sapaan, pemakaian partikel, bentuk perulangan atau reduplikasi, bentuk kata, variasi bahasa, dan dialek Bangkalan.

Kata Kunci: etnik Madura, ranah pendidikan, sosiolinguistik, komponen tutur, pemakaian bahasa.

\section{Pendahuluan}

Etnik Madura merupakan etnik yang mempunyai tingkat mobilitas tinggi karena hampir di kota-kota besar
Indonesia terdapat komunitas etnik Madura. Ini menandakan bahwa daerah tujuan merantau etnik Madura mencakup seluruh pelosok tanah air

" Kundharu Saddhono adalah Dosen Jurusan Pendidikan Bahasa dan Seni FKIP Universitas Sebelas Maret Surakarta. 
dan telah berlangsung beberapa abad yang lalu (Wiyata, 2001). Etnik Madura pertama kali datang ke Surakarta tidak dapat dikatakan secara pasti. Sumber tradisional seperti Babad Sala (RM Sajid, 1984) hanya menyebutkan bahwa orang dari tanah sabrang atau mancanegara wetan datang ke Surakarta untuk mengabdi sebagai prajurit di Keraton Surakarta Hadiningrat. Pada masa Paku Buwana III (1749-1778) dalam pasukan keraton Lombok Abang terdapat prajurit dari Madura. Mereka bermukim di kampung yang bernama Sampangan. Kata Sampangan berasal dari Sampang, sebuah kabupaten di Madura. Sebenarnya Kampung Sampangan tersebut merupakan sebutan umum untuk kampung orang Madura, yang semua dianggap berasal dari Sampang, Madura (Radjiman dalam Sutirto, 2000). Atas dasar kenyataan itu, maka cikal bakal etnik Madura yang bekerja sebagai abdi dalem kurang lebih dua abad tersebut merupakan etnik Madura yang pertama kali datang ke Surakarta.

Jumlah masyarakat etnik Madura di Surakarta (MEMS) saat ini tidak dapat diketahui secara pasti. Hasil penelitian (1993) menginformasikan bahwa jumlahnya 4.069 orang. Menurut Ahmad Tohir (2002),
Sekretaris Rukun Keluarga Madura (RKM), jumlah etnik Madura saat ini kurang lebih 5.000-an termasuk yang tinggal di daerah pinggiran. Hal yang sama dinyatakan oleh Amir Tohir (2002), sesepuh Paguyuban Remaja Islam Madura (PRISMA), MEMS sebagian besar bekerja di sektor jasa dan perdagangan sektor informal kota, seperti penjual sate, pejual soto, tukang cukur, tukang kasur, tukang besi tua dan lain-lain. Selain itu, juga ada yang bekerja sebagai pegawai negeri dan swasta tetapi jumlahnya sangat kecil.

Seperti halnya bahasa Jawa (BJ), apabila sistem stratifikasi sosial dikaitkan dengan jenis-jenis tingkatan bahasa yang digunakan dalam masyarakat, maka posisi sosial seseorang akan menentukan pilihan tingkatan bahasa yang digunakan. A. Latief Wiyata (2002) menyebutkan bahwa tingkatan bahasa atau dagondagga basa dalam bahasa Madura (BM) ada lima, yaitu (1) bahasa keraton misalnya abdi dalem 'saya' dan junan dalem 'kamu', (2) bahasa tinggi, seperti abdina 'saya' dan panjenengan 'kamu', (3) bahasa halus: kaula 'saya' dan sampeyan 'kamu', (4) bahasa menengah: bula 'saya' dan dika 'kamu', dan (5) bahasa kasar atau mapas: sengko' 'saya' dan ba' 'saya' atau kake 'kamu' dan seda 'kamu'. 
Etnik Madura menarik dikaji dalam konteks sosial kebahasaan karena, (1) sifat orang Madura yang ekspresif, spontan, dan terbuka senantiasa termanifestasikan ketika harus merespon sesuatu yang dihadapi, khususnya terhadap perlakuan orang lain atas dirinya, (2) latar belakang bahasa daerah yang masih serumpun dengan bahasa Jawa, seperti adanya tingkatan bahasa, pernyataan ini merujuk pendapat Uhlenbeck (1964), (3) etnik Madura mempunyai organisasi sosial yang berorientasi pada asal daerahnya, pernyataan ini mengacu pendapat Usman Pelly (1994). Organisasi etnik Madura di Surakarta bernama Rukun Keluarga Madura (RKM) yang digagas oleh Asnawi pada tahun 1957 merupakan lanjutan dari Rukun Kematian Madura (dalam Sutirto, 2000: 114). Selain itu juga ada Paguyuban Remaja Islam Madura (PRISMA) dan Ikatan Istri Madura (IKIM), dan (4) Madura merupakan etnik yang paling banyak di Surakarta, kurang lebih $1 \%$ dibandingkan dengan jumlah penduduk Surakarta, yaitu sekitar 5.000-an orang dari sekitar 550.251 orang (BPS, 2002).

Berdasarkan hal tersebut di atas, maka rumusan masalah dalam tulisan ini yaitu, (1) bagaimanakah pilihan bahasa yang digunakan masyarakat etnik Madura di Surakarta pada ranah pendidikan, (2) bagaimanakah fungsi pilihan bahasa masyarakat etnik Madura di Surakarta pada ranah pendidikan, dan (3) bagaimanakah kekhasan pemakaian bahasa masyarakat etnik Madura di Surakarta pada ranah pendidikan.

Adaun tujuan penelitian dalam tulisan ini adalah, (1) memaparkan pilihan bahasa yang digunakan masyarakat etnik Madura di Surakarta pada ranah pendidikan, (2) menjelaskan fungsi pilihan bahasa masyarakat etnik Madura di Surakarta pada ranah pendidikan, dan (3) mendeskripsikan kekhasan pemakaian bahasa masyarakat etnik Madura di Surakarta pada ranah pendidikan.

\section{Kajian Literatur}

Tulisan ini merupakan kajian di bidang sosiolinguistik. Kajian sosiolinguistik yang berfokus pada pilihan bahasa masyarakat yang multilingual telah dilakukan oleh beberapa peneliti, antara lain Giles (1979), dan Susan Gal (1979), Sumarsono (1993), Markamah (2000), dan Saddhono (2004). Dalam penelitian-penelitian tersebut dijelaskan bahwa faktor perpindahan atau migrasi penđuduk dalam suatu masyarakat -yang menyebabkan mereka sebagai kelompok 
minoritas - sangat berperan dalam menentukan situasi kebahasaan.

Dalam kajian sosiolinguistik ada tiga jenis pilihan bahasa yang biasa dikenal, yaitu campur kode, alih kode, dan variasi dalam bahasa yang sama (variation within the same language). Campur kode merupakan salah satu aspek dari saling ketergantungan bahasa (language dependency) di dalam masyarakat multilingual. Yang dimaksud adalah bahwa dalam masyarakat multilingual hampir tidak mungkin seorang penutur menggunakan satu bahasa secara mutlak murni tanpa sedikit pun memanfaatkan bahasa atau unsur bahasa lain. Campur kode pada dasarnya yaitu pemakaian dua bahasa atau lebih dengan saling memasukkan unsur bahasa yang satu ke bahasa yang lain dan melibatkan unsur kebahasaan dari tingkat kata sampai klausa. Alih kode mempunyai beberapa pengertian, di antaranya dinyatakan Alwasilah (1989) bahwa perpindahan satu dialek ke dialek lainnya dalam satu bahasa disebut dialect switching atau code switching atau alih kode. Suwito (1997) berpendapat bahwa alih kode adalah peralihan dari kode yang satu ke kode yang lain. Maksudnya bila seorang penutur pertama-tama menggunakan kode A (misalnya bahasa Indonesia (BI)) kemudian beralih ke kode B (misalnya bahasa Jawa ). Pemakaian dua bahasa atau lebih dalam alih kode ditandai oleh masing-masing bahasa masih mendukung fungsi-fungsi tersendiri sesuai dengan konteksnya dan fungsi masing-masing bahasa disesuaikan dengan situasi yang relevan dengan perubahan kodenya. Jenis pilihan bahasa yang terakhir yaitu variasi dalam bahasa yang sama, sering menjadi fokus kajian tentang sikap bahasa. Misalnya, kajian yang pernah dilakukan terhadap variasi lafal baku bahasa Inggris dan lafal bahasa Inggris yang "berat" yang biasa dipakai di wilayah Welsh; atau bentuk ngoko dan krama dalam BJ, karena variasi unda-usuk dalam BJ tersebut ada dalam "bahasa yang sama". Maka, apabila kita menganggap "variasi dalam bahasa yang sama" tersebut sebagai suatu masalah pilihan bahasa, pilihan bahasa tersebut mencakup penutur ekabahasawan dan dwibahasawan, baik alih kode atau campur kode (Sumarsono, 2002).

Pilihan bahasa yang dilakukan oleh masyarakat yang multilingual ditentukan oleh berbagai faktor dan mempunyai makna sosial tertentu. Hodges dan Kuess (1991) menyatakan bahwa bahasa (code) 
tidak bisa dipelajari atau sepenuhnya dipahami apabila tidak dikaitkan dengan masyarakat pemakainya, sehingga bahasa lisan harus dilihat dalam konteks teori keseluruhan sistem tanda yang terbentuk dan diperlakukan secara sosial sebagai kebiasaan masyarakat. Berkaitan dengan hal tersebut, dalam kajian ini akan mengungkapkan makna semiotik sosial yang berkaitan dengan pilihan dan pemakaian bahasa etnik Madura di Surakarta. Bahasa sebagai semiotik sosial berarti bahasa sebagai tanda yang penggunaannya menggambarkan sistem sosial budaya suatu masyarakat (Wierzbicka, 1996).

Ranah atau domain sosial adalah kelompok situasi sosial yang dibakukan, secara khas dibatasi oleh seperangkat kaidah tingkah laku yang umum, misalnya domain sosial keluarga adalah rumah, domain sosial keagamaan adalah masjid. Domain sosial sangat penting dalam analisis latar multibahasa yang melibatkan beberapa penutur. Domain sosial dipergunakan untuk menghubungkan keragaman pilihan bahasa dan topik oleh individu-individu terhadap kaidah budaya masyarakat yang lebih luas dan kelancaran dalam berinteraksi (Crystal, 1993). Fasold (1993) secara singkat mendefinisikan ranah sebagai konstelasi faktor-faktor lokasi, topik, dan partisipan. Sementara itu, Romaine (1995) berpendapat bahwa ranah adalah abstraksi yang mengacu pada suasana aktivitas yang mewakili gabungan waktu khusus (spesific times), latar, dan hubungan peran. Tulisan ini hanya akan membahas pemakaian bahasa masyarakat tutur Madura di Surakarta pada ranah atau lingkungan pendidikan

\section{Metode Penelitian}

Kajian ini dilaksanakan di Kota Surakarta, Jawa Tengah dengan alasan bahwa Surakarta merupakan salah satu daerah pemakai BJ baku yang ditandai dengan adanya lafal umum yaitu vokal rendah bulat [0] dan pemakaian ungggah-ungguhing basa (Dwiraharjo, 2001). Selain itu, Surakarta dahulu merupakan pusat kebudayan Jawa yang ditandai dengan Keraton Surakarta Hadinigrat dan Pura Mangkunegaran. Hal ini memperlihatkan bahwa budaya dominan Jawa, yang secara langsung maupun tidak langsung akan mempengaruhi pemakaian bahasa masyarakat etnik Madura - yang merupakan etnik minoritas - dalam berinteraksi dengan masyarakat etrik Madura sendiri atau di luar etnik Madura. Kajian ini mengambil lokasi di lima kecamatan yaitu Jebres, Pasar 
Kliwon, Serengan, Banjarsari, dan Laweyan. Lokasi difokuskan di tempat-tempat yang dihuni oleh masyarakat etnik Madura dan dalam masyarakat tersebut terdapat aktivitas-aktivitas sosial budaya etnik Madura.

Data diambil dari pemakaian bahasa etnik Madura di Surakarta yang terjadi secara alami yang mempunyai ciri-ciri khusus sesuai dengan tujuan. Secara alami artinya bahwa pemakaian bahasa atau peristiwa bahasa itu berlangsung secara wajar di masyarakat dalam kegiatan komunikasi berbahasa sehari-hari secara lisan. Metode pengumpulan data yang digunakan adalah metode simak dan metode cakap (Sudaryanto, 1995). Adapun mengenai teknik lanjutannya menggunakan teknik simak libat cakap, teknik rekam, dan teknik catat. Pengumpulan data juga menggunakan teknik wawancara mendalam (indepth-interviewing).

Kajian ini menggunakan teknik cuplikan yang bersifat selektif dengan menggunakan pertimbangan berdasarkan konsep teoretis yang digunakan, keingintahuan pribadi penulis, karakteristik empirisnya dan lain-lain. Oleh karena itu, cuplikan yang digunakan dalam kajian ini lebih bersifat purposive sampling, atau lebih tepat disebut sebagai cuplikan dengan criterion-based selection (Goetz \& LeCompte dalam Sutopo, 1996).

Soepomo Poedjosoedarmo (dalam Dwiraharjo, 2001) menyatakan bahwa penelitian sosiolinguistik pada dasarnya adalah penelitian kontekstual. Penelitian kontekstual adalah penelitian mengenai wujud tuturan (bahasa) dengan memperhatikan konteks sosial yang menyertai terjadinya suatu tuturan. Dalam analisis data akan diperhitungkan konteks sosial yang berupa komponen tutur, yaitu (1) penutur atau pembicara, (2) mitra tutur atau lawan tutur, (3) situasi tutur atau situasi bicara, (4) tujuan tuturan, dan (5) hal yang dituturkan (Sudaryanto, 1995).

\section{Hasil Penelitian dan Pembahasan \\ 4.1 Wujud Pilihan Bahasa di Ranah Pendidikan}

MEMS merupakan masyarakat dwibahasawan, karena selain menguasai bahasa daerahnya yaitu bahasa Madura (BM), MEMS juga menguasai $\mathrm{BI}$ yang merupakan bahasa nasional dan BJ sebagai bahasa setempat di Surakarta. Kontak bahasa antara ketiga bahasa tersebut sangat dimungkinkan karena situasi dan kondisi tertentu yang mengakibatkan BC antara BM, BI, dan BJ. 


\section{Kundharu Saddhono}

Hasil kajian ini mengenai pilihan bahasa yang dilakukan MEMS di ranah pendidikan yang berupa, (1) bahasa Madura (BM), (2) bahasa Jawa (BJ), (3) bahasa Indonesia (BI), dan (4) bahasa campuran (BC) yang terbagi atas $\mathrm{BM}$ dan $\mathrm{BJ}, \mathrm{BM}$ dan $\mathrm{BI}$, $\mathrm{BJ}$ dan $\mathrm{BI}$, serta ketiga bahasa $\mathrm{BM}$, $\mathrm{BJ}$, dan BI.

Perlu dijelaskan bahwa ranah pendidikan yang dimaksud di sini adalah lingkungan di mana terjadi proses pendidikan baik formal maupun nonformal dan di luar lingkungan keluarga, lingkungan sosial, lingkungan jaringan kerja, dan lingkungan keagamaan. Peristiwa tutur yang masuk dalam kategori ini misalnya proses belajar mengajar di sekolah formal dan proses belajar mengajar di Tamam Pendidikan
Alquran (TPA)

Dalam penelitian ini, data yang berupa peristiwa tutur di lingkungan pendidikan secara khusus tentang pengajaran BM di Surakarta tidak ditemukan oleh penulis. BM yang digunakan MEMS di lingkungan pendidikan ini dapat digolongkan menjadi dua, yaitu (1) antara murid dan murid dan (2) antara guru atau ustadz dengan murid

Data [1] merupakan peristiwa tutur yang terjadi dalam lingkungan sekolah, tepatnya pada waktu pagi hari sebelum kegiatan sekolah dimulai. Peristiwa tutur tersebut melibatkan penutur yang berasal dari etnik Madura dan merupakan peristiwa tutur yang terjadi antara murid dan murid.

\section{[1] (1) A : [tugaseh h?D?h la mar?h]}

/ tugasmu / sudah / selesai / 'Tugasmu sudah selesai?'

(2) B : [mar?h tap?h se nəm?r sa?a? s??kっ? ta? tash j?w?bnah. mlarat]

/ sudah / tapi / yang / nomor / sembilan / aku / tidak / tahu / jawabnya / sulit /

'sudah tapi yang nomor sembilan aku tidak tahu jawabnya. sulit' 
(3) A : [s??kJ? se nom?r sa?a? tah bisa kia tapeh s??kə? lamar?h ekalaksh j?w?bnah t?llo? sat???a]

/ aku / juga / yang / nomor / sembilan / tidak / bisa / tapi / aku / sudah / kerjakan / jawabannya / tiga / setengah /

'aku juga yang nomor sembilan tidak bisa tapi aku sudah kerjakan jawabannya tiga setengah'

(4) B : [t?llo? sat???a ta? j?w?bhen p?tto? riah]

/ tiga / setengah / jawabanku / tujuh / ini /

'tiga setengah? jawabanku tujuh. Ini'

(5) A : [ni?guh tugas h?D?h. nom?r sa?a? riah gils? e bagi due? bI? $s$ ?D?h. ariah hoDunah e $b$ ?gi due? polanah $g$ ?l?? e kal?h dueh kabhi j?w?b?h D?DIh tells? sat???a]

/ lihat / tugasmu / nomor / sembilan / ini / belum / kamu / bagi / dua / ini / harus / dibagi / dua / karena / tadi / dikali / dua / semua / jadi / jawabannya / tiga / setengah /

'lihat tugasmu. nomor sembilan ini belum kamu bagi dua. ini harus dibagi dua karena tadi dikali dua semua jadi jawabannya tiga koma lima'

(6) B : [0 iy?h, ni?guh tugaseh $h$ ?D?h se laen]

/o / ya / lihat / tugas / kamu / yang / lain /

'o ya. lihat tugas kamu yang Jain'

(7) A : [ariah nom?r situ? j?w?bnah l?ma? koma s?g?mI?, nom?t due? empa? b?l?s, nom? t? lls? duek koma p?to? l? ma?, nom?r empa? p?ts? psls ?n?m, nom?r l?mak salekər, nom?r ?n?m sab?1?s, nom?r pets? b?llu? nom?r belu? empa? pəls situng, nom?r sa? ak t?ls? koma l?mak, ariah andi? ?h h?D?h sala, nom $\chi$ r sapsls sag?mI?. kabbhi paD?h coma se nom?r sa?a? g?l?? s?laen]

/ ini / nomor / satu / jawabannya / lima / koma / dua lima / nomor / dua / empat / belas / nomor / tiga / dua / koma / tujuh / lima / nomor / empat / tujuh / puluh / enam / nomor / lima / dua / puluh / satu / nomor / enam / sebelas / nomor / tujuh / delapan / nomor / delapan / empat / puluh / satu / nomor / sembilan / tiga / koma / lima / ini / punya / kamu / salah / nomor / sepuluh / dua / puluh / lima / semua / sama / hanya / yang / nomor / sembilan / tadi / yang / beda/

'ini nomor satu jawabannya lima koma dua lima $(5,25)$, nomor dua empat belas (14), nomor tiga dua koma tujuh lima $(2,75)$, nomor empat tujuh puluh enam (76), nomor lima dua puluh satu (21), nomor enam sebelas (11), nomor tujuh delapan (8), nomor delapan empat puluh satu (41), nomor sembilan tiga koma lima $(3,5)$, ini punya kamu salah, nomor sepuluh dua puluh lima (25). semua sama hanya yang nomor sembilan tadi yang beda'

(8) B : [iyUt]

/ya/ 
Pelaku : Pt adalah seorang anak laki-laki yang berlatar belakang etnik

Tuturan Madura dan merupakan teman sekolah Mt

Mt adalah seorang anak laki-laki yang berlatar belakang etnik Madura dan merupakan teman sekolah Pt.

Situasi : Tuturan terjadi dalam situasi nonformal dan santai karena

Tuturan terjadi antarteman sekolah yang berusia sebaya.

Topik : Pekerjaan rumah. Anak sekolah yang berdiskusi mengenai

Tuturan pekerjaan rumah mereka dengan mencocokkan jawaban soal satu per satu.

Lokasi : Tuturan terjadi di dalam ruang kelas sekolah Pt dan Mt

Tuturan Laweyan, Surakarta.

Pilihan bahasa yang digunakan penutur (Pt) dan mitra tutur (Mt) dalam data [1] adalah BM. Ini dilatarbelakangi oleh bahasa ibu mereka yaitu BM dan kebiasaan mereka yang selalu menggunakan $\mathrm{BM}$ jika berkomunikasi dengan teman yang berasal dari Madura. Selain itu, situasi yang akrab juga menjadi faktor penentu pilihan bahasa tersebut. Keakraban itu muncul karena peristiwa tutur tersebut hanya melibatkan Pt dan Mt yang mempunyai latar belakang yang sama yaitu etnik Madura.

Dari data [1] tersebut dapat kita lihat hal yang menarik yaitu kata iyeh [1.6] dan iyut [1.8]. Kedua kata tersebut mempunyai arti yang sama dalam BI yaitu 'iya'. Ketika penulis menanyakan kepada narasumber tentang pemakaian kata iyeh dan iyut diketahui bahwa pemakaian katakata tersebut merupakan kebiasaan dari penutur masing-masing dan tidak ada yang membedakan antara kedua kata tersebut. Dalam tuturan seharihari kata yang sering muncul adalah iyeh. Kita bisa bandingkan hal-hal yang sering digunakan masyarakat Madura yaitu kata taiyeh yang berarti 'iyakan' dan bukannya kata taiyut.

Peristiwa tutur pada data [1] juga memberikan informasi tentang angka dari BM. Hal itu dapat dilihat dari Tabel di bawah ini dengan beberapa informasi yang diperoleh dari wawancara.

Temuan hasil penelitian mengenai bahasa campur (BC) antara $\mathrm{BM}, \mathrm{BJ}$, daan BI juga tampak di lingkungan pendidikan, seperti pada 
Tabel Perbandingan Angka

Bahasa Indonesia, Bahasa Madura, dan Bahasa Jawa

\begin{tabular}{|c|l|l|l|}
\hline No & Bahasa Indonesia (BI) & Bahasa Madura (BM) & \multicolumn{1}{|c|}{ Bahasa Jawa (BJ) } \\
\hline$(1)$ & \multicolumn{1}{|c|}{$(2)$} & \multicolumn{1}{c|}{$(3)$} & \multicolumn{1}{c|}{$($ (4) } \\
\hline 1 & Satu & Setong [s?tts?] & Siji [siji] \\
\hline 2 & Dua & Duek [du??] & Loro [loro] \\
\hline 3 & Tiga & Tellok [t?lb?] & Telu [t?lu] \\
\hline 4 & Empat & Empak [?mpa?] & Papat [papat] \\
\hline 5 & Lima & Lemak [lema?] & Lima [lims] \\
\hline 6 & Enam & Ennem [?nn?m] & Enem [?n?m] \\
\hline 7 & Tujuh & Pettok [pets?] & Pitu [pitu] \\
\hline 8 & Delapan & Belluk [b?llU?] & Wolu [wslu] \\
\hline 9 & Sembilan & Sangak [sa?a?] & Sanga [sa?a] \\
\hline 10 & Sepuluh & Sapolo [sapsls] & Sepuluh [s?pulUh] \\
\hline 11 & Dua Puluh Lima & Segemek [s?g?me?] & Selawe [s?lawe] \\
\hline
\end{tabular}

data [2]. BC pada peristiwa tutur data [2] menunjukkan bahwa pelaku tutur adalah orang yang berasal dari etnik Madura antara ustadz dan santri.

[2] (1) A : Pak, besok sabtu sore latihan tidak?

(2) B : [ys latihan, ws? isIh duru? ksmpa?. Zul, b?ss? Aja? Ali kүmarIn dia tida? Ikut latihan kan] 'ya latihan, orang masih belum kompak. Zul, besok ajak Ali, kemarin dia tidak ikut latihan kan?'

(3) A : [wah, ali sama?ken b?D?h ecsmps?h taretanah se t?ppa?h g?Duan haj?t]

/ wah / ali / sekarang / di / rumah / saudaranya / yang / sedang / hajatan /

"wah, Ali sekarang di rumah saudaranya yang sedang hajatan'

(4) B : [bil?h ab?linah, t? rus bagaimana] / kapan / kembalinya / terus / bagaimana / 'kapan kembalinya? terus bagaimana?'

(5) A : Katanya minggu depan. Kita cari yang lain saja, Pak?

(6) B : Boleh, siapa yang bisa gantikan.

(7) A : Ahmad dan Choirul bisa. Nanti saya cari.

(8) B : Ya. 
Pelaku : Pt adalah seorang laki-laki yang berlatar belakang etnik Tutur Madura dan merupakan seorang ustadz yang mengajar di Taman Pendidikan Alquran.

Mt adalah seorang anak laki-laki yang berlatar belakang etnik Madura dan merupakan anak didik atau santri Pt.

Situasi : Tuturan terjadi dalam situasi santai karena terjadi di luar Tuturan kegiatan belajar mengajar, hanya status antara Pt dan Mt berbeda.

Topik : Membahas latihan rebana. Pt bertanya kepada Mt kapan Tuturan akan latihan dan yang menggantikan posisi Zul karena tidak bisa latihan, sedang di rumah saudaranya yang sedang hajatan.

Lokasi : Tuturan terjadi di sebuah TPA"Al-Muhajirin, Jebres, Tuturan Surakarta.

Data [2] menunjukkan bahwa pelaku tutur dalam peristiwa tutur tersebut terdapat tiga bahasa yang digunakan yaitu BM, BJ, dan BI. BC terjadi di lingkungan pendidikan tersebut dikarenakan pelaku tutur sebagai faktor utamanya. BI muncul karena situasi yang formal di lingkungan pendidikan. BJ muncul karena situasi spontan Pt yang mendengar pernyataan Mt. Sedangkan BM muncul karena kebiasaan dari Pt dan Mt yang dipengaruhi juga oleh bahasa ibu mereka yaitu BM. Selain itu juga spontanitas dari $\mathrm{Pt}$ yang terekspresikan dengan BM.

Pt pada awal peristiwa tutur menggunakan $\mathrm{BI}$ dipengaruhi oleh situasi tuturan yang formal yaitu di lingkungan pendidikan. Pada saat ini proses belajar mengajar sudah selesai akan tetapi lokasi tuturan masih di lingkungan pendidikan. Pada data [2.3] terlihat bahwa Pt melakukan alih kode ke BM karena rasa spontan. Pada situasi spontan umumnya seseorang mengekspresikan dengan bahasa ibunya. Pada tuturan selanjutnya [2.5], Pt belakukan alih kode ke BI lagi karena untuk mengimbangi tuturan Mt yang bertanya dengan BI.

Mt dalam peristiwa tutur data [2] menggunakan tiga bahasa yaitu BM, BJ, dan BI. Pada awal tuturan ketika menjawab pertanyaan $\mathrm{Pt}, \mathrm{Mt}$ menggunakan BJ karena kebiasaan Mt yang selalu menggunakan $\mathrm{BJ}$ dalam aktivitas sehari-hari. Pada peristiwa tutur yang sama [2.2] melakukan alih kode ke BI karena 
peristiwa tutur tersebut masih di lingkungan pendidikan. Kemudian pada tuturan [2.4], Mt menggunakan $\mathrm{BM}$ untuk mengimbangi $\mathrm{Pt}$ yang berkomunikasi dengan BM. Akan tetapi pada tuturan yang sama data [2.4], Mt melakukan alih kode ke BI lagi karena terbawa situasi yang masih ada di lingkungan pendidikan.

\subsection{Fungsi Pilihan Bahasa Madura di Ranah Pendidikan}

Pilihan bahasa yang dilakukan oleh MEMS dapat dikategorikan menjadi 4 yaitu (1) pilihan $B M,(2)$ pilihan $B J$, (3) pilihan $\mathrm{BI}$, dan (4) pilihan $\mathrm{BC}$. Pilihan BC oleh MEMS masih dibagi menjadi empat macam, yaitu (1) BM dan BJ, (2) BM dan BI, (3) BJ dan BI, dan (4) ketiga bahasa sekaligus yaitu BM. BJ dan BI.

Pilihan BM yang dilakukan oleh MEMS dipengaruhi oleh beberapa faktor. Faktor penentu utama pilihan BM yang dilakukan MEMS adalah PK yang didukung oleh latar belakang bahasa yang dominan yaitu BM. MEMS sebagai masyarakat perantau jika berkomunikasi dengan etnik Madura sendiri akan lebih tepat menggunakan BM. Selain itu faktor PK. juga memegang peran yang penting. Dalam sebuah keluarga Madura jika Pt dan Mt berasal dari Madura maka dapat dipastikan menggunakan BM, kecuali jika pada situasi dan kondisi tertentu. Sebagai contoh yaitu dalam keluarga tersebut hadir orang ketiga yang bukan berasal dari etnik Madura. Penelitian ini juga menemukan sebuah fenomena bahwa dalam lingkungan keluarga BM dipakai oleh hampir MEMS yang sudah dewasa. Secara umum dapat digambarkan bahwa BM yang dipakai oleh MEMS adalah bentuk BM yang biasa. BM halus jarang sekali muncul dan hanya muncul pada saat tertentu saja, misalnya seperti peristiwa tutur yang melibatkan seorang ustadz atau pada perkenalan awal. Secara umum fungsi pilihan BM yaitu makna kekeluargaan, keakraban, ungkapan perasaan, menjaga kerahasiaan, identitas etnik, dan pemertahanan budaya.

Pilihan BJ hampir seluruhnya mewarnai pemakaian bahasa MEMS di lingkungan pendidikan. Hal ini mengingat $\mathrm{BJ}$ merupakan bahasa yang dipakai di Surakarta, hampir seluruh kegiatan yang dilakukan dalam masyarakat Surakarta menggunakan $\mathrm{BJ}$, kecuali pada saat situasi formal atau resmi. Faktor penentu utama pilihan $\mathrm{BJ}$ ini adalah $\mathrm{PK}$ yang melibatkan orang Jawa, sebagai masyarakat yang paling dominan. $\mathrm{Hal}$ ini juga didukung oleh LT yang berada 
di Jawa, khususnya Surakarta. Selain itu, MEMS sebagai masyarakat perantau maka maud tidak mau harus menguasai BJ sebagai sarana komunikasi dengan masyarakat dan sebagai sarana untuk sosialisasi, adaptasi dan integrasi. Secara umum fungsi pilihan BJ yaitu komunikasi dengan masyarakat, kebiasaan, adaptasi, dan keakraban.

Pilihan BI oleh MEMS digunakan dalam situasi formal atau resmi dan situasi itu sebagian besar berada di lingkungan pendidikan. Faktor utama yang menjadi dasar pilihan BI adalah ST yang didukung oleh domain sosial. Seperti dikemukakan sebelumnya bahwa BI ini muncul pada situasi yang formal. Dalam komunikasi konvensional juga digunakan pada saat perkenalan awal. Misalnya di warung sate ketika pejual membuka komunikasi. BI juga dipakai oleh MEMS di lingkungan keluarga, tetapi menurut pengamatan penulis BI yang digunakan di lingkungan keluarga untuk tujuan pendidikan atau sekadar bergengsi. Secara umum fungsi pilihan BI yaitu situasi formal atau resmi, komunikasi antaretnik, sekadar bergengsi, pendidikan, dan pertemuan awal.

MEMS selain menggunakan ketiga bahasa tersebut yaitu BM, BJ, dan $\mathrm{BI}$ dalam berkomunikasi, juga kadang-kadang menggunakan bahasa tersebut secara bersama-sama atau bercampur. Dapat digambarkan di sini bahwa ketika $B C$ yang dipakai oleh MEMS di dalamnya terdapat BM maka dapat digambarkan bahwa $\mathrm{BC}$ tersebut paling dominan terjadi dan apabila dalam BC di dalamnya terdapat BI maka paling dominan terjadi di lingkungan pendidikan. Faktor utama munculnya $\mathrm{BC}$ adalah ST yang nonformal. Secara umum fungsi pilihan $\mathrm{BC}$ yaitu situasi yang nonformal, penegasan pesan, dan konsep baru.

\subsection{Kekhasan Bahasa Etnik Madura diSurakarta pada Ranah Pendidikan}

Pilihan bahasa MEMS dapat dirangkum dalam pola-pola pemakaian bahasa yaitu, pertama, dalam peristiwa tutur yang berlangsung sesama etnik Madura bahasa yang digunakan adalah bahasa ibu mereka yaitu BM. Pilihan BM ini disebabkan antara lain yaitu kebiasaan, sebagai identitas, menjaga kerahasiaan dan pemertahanan budaya etnik Madura. Kedua, apabila dalam peristiwa tutur tersebut melibatkan orang di luar etnik Madura maka bahasa yang digunakan adalah BJ atau BI tergantung dari partisipan. 
Faktor penentu utama pilihan $\mathrm{BM}$ adalah pelaku tuturan (PK) yang didukung oleh domain sosialnya, yaitu lokasi tutur (LT), situasi tutur (ST), dan topik tuturan (TT). MEMS sebagai masyarakat perantau jika berkomunikasi dengan etnik Madura sendiri akan lebih tepat menggunakan BM. Selain itu, faktor PK juga memegang peran yang penting. Dalam sebuah keluarga Madura jika Pt dan Mt berasal dari Madura maka dapat dipastikan menggunakan BM, kecuali jika pada situasi dan kondisi tertentu. Kajian ini juga menemukan sebuah fenomena bahwa dalam lingkungan keluarga BM dipakai oleh hampir MEMS yang sudah dewasa. Secara umum dapat digambarkan bahwa BM biasa yang sering dipakai. $\mathrm{BM}$ halus jarang muncul dan hanya muncul pada saat tertentu saja, misalnya seperti peristiwa tutur yang melibatkan seorang ustadz atau pada perkenalan awal. Pilihan BJ muncul dalam peristiwa tutur etnik Madura jika di LT tersebut terdapat masyarakat di luar etnik Madura atau pembicaraan itu melibatkan anak kecil. Sedangkan $\mathrm{BI}$ muncul hanya pada keluargakeluarga tertentu saja dan pada situasi tertentu. Keluarga tertentu adalah keluarga yang 'mampu', biasanya ketika berkomunikasi dengan anaknya sering menggunakan BI.
Kekhasan pemakaian bahasa MEMS adalah pemertahanan kata sapaan dalam BM. Sebagai contoh bentuk rasa hormat seorang $\mathrm{Pt}$ kepada $\mathrm{Mt}$, baik karena umur, status, dan lain-lain akan menggunakan kata sapaan kak atau sampenyan untuk laki-laki dan bukan kata mas walaupun dalam tuturan tersebut menggunakan BJ atau BI. Bentuk kata sapaan yang masih digunakan oleh MEMS antara lain yaitu bug 'kakak perempuan', alek lakek 'anak lakilaki, alek binek 'anak perempuan' dan sebagainya. Akan tetapi jika digunakan di luar lingkungan MEMS, kata sapaan tersebut bercampur dengan kata sapaan BJ yaitu mas, mbakyu atau yu, thole, dan ndhuk. Hal lain yang menarik adalah kata sapaan untuk orang tua yaitu ayah dan ibu. MEMS ada yang menggunakan kata sapaan bahasa Arab (BA). Kata tersebut adalah $a b i$ untuk menyebut ayah dan $u m i$ untuk menyebut ibu.

Kekhasan pemakaian bahasa MEMS yang lain adalah munculnya partikel-partikel baik dari BM maupun BJ, Partikel-partikel yang muncul tersebut antara lain $l$ he, le, bik yang berasal dari BM dan lho, to, kok yang berasal dari BJ. Kehadiran partikelpartikel tersebut mempunyai fungsi sendiri-sendiri, misalnya sebagai 
penegasan untuk kata tho atau the atau mempertanyakan untuk kata kok atau bik. Partikel-partikel tersebut muncul disebabkan tuturan yang ada merupakan sebuah dialog atau wacana lisan yang nonformal sehingga baik disadari ataupun tidak muncul dalam tuturan. Selain itu kedekatan hubungan PK yang menyebabkan ST menjadi informal juga menjadi salah satu faktor muncuinya partikel-partikel tersebut.

Kekhasan pemakaian bahasa MEMS terlihat juga pada bentuk kata perulangan. Pembentukan perulangan tersebut serupa dengan kata boh aboh 'aduh-aduh' yang sangat populer di kalangan masyarakat. Bentuk tersebut merupakan perulangan yang dimaksudkan untuk penegasan tuturan atau penekanan pada kata tertentu. Bentuk ini bisa terjadi pada kata sifat maupun kata benda tergantung penegasan tiap tuturan. Kata yang mempunyai tipe serupa antara lain teh ngateh 'hatihati', nak kanak 'anak-anak', leh melleh 'membeli' dan lain-lain. Temuan hasil kajian ini menegaskan bahwa bentuk perulangan ini memang sangat produktif dalam tuturan lisan masyarakat etnik Madura.

Bentuk kata yang populer dalam masyarakat yang jarang dijumpai dalam peristiwa tutur MEMS yaitu bentuk taiyeh 'iyakan'. Bentuk kata ini jarang dijumpai dalam peristiwa tutur MEMS kecuali hanya pada situasi santai, khususnya bercanda dan frekuensinya terbatas. Yang lebih menarik justru pemakaian kata iyeh 'iya' sendiri yang merupakan bentuk dasar taiyeh 'iyakan'. Kata taiyeh mempunyai variasi bentuk yaitu yeh, iyut, yut untuk BM biasa. Pemakaian kata-kata tersebut tidak berbeda maknanya dalam setiap tuturan. Kemunculan bentuk kata tersebut tergantung dari kebiasaan $\mathrm{Pt}$ dalam menggunakannya sehari-hari. Bentuk ini juga mempunyai bentuk halus yaitu enggi 'ya' yang sering digunakan oleh Pt yang menghormati Mt-nya, seperti tuturan yang terjadi antara santri dan kiai.

Kekhasan yang lain mengenai pemakaian bahasa MEMS adalah ragam dialek Bangkalan, karena sebagian besar masyarakat Madura yang tinggal dan menetap di Surakarta berasal dari Madura bagian barat atau yang mempunyai dialek Bangkalan. Dalam masyarakat Madura terdapat tiga macam dialek yaitu sebagai berikut.

(1) Dialek Bangkalan mempunyai kebiasaan atau ciri menyingkat kata-kata sehingga dengan demikian banyak terdapat bunyi 
konsonan rangkap karena ada bunyi vokal yang tidak diucapkan seperti:jareya [jråya] 'ini' dan pasera [psåra] 'siapa'

(2) Dialek Pamekasan mempunyai kebiasaan atau ciri mengucapkan kata sesuai dengan jumlah kata, jadi panjangnya suku kata diucapkan sama, seperti: jareya [jarâya] 'ini' dan pasera [pasåra] 'siapa'.

(3) Dialek Sumenep mempunyai kebiasaan atau ciri memperpanjang ucapan kata bagian akhir, umumnya pada kata yang berakhir dengan vokal, seperti: jareya [jaråyaa] 'ini' dan pasera [pasåraa] 'siapa'.

\section{Simpulan dan Saran}

\subsection{Simpulan}

Berdasarkan hasil analisis dan pembahasan terhadap data mengenai pemakaian bahasa etnik Madura di Surakarta pada ranah pendidikan dapat ditarik simpulan besar dengan rincian sebagai berikut.

(1) Pilihan bahasa MEMS di ranah pendidikan yang diamati dapat digolongkan menjadi 4 bentuk yaitu sebagai berikut.

a. Pilihan BM; faktor utama yang mempengharuhi pemakaian ini adalah PK yang berasal dari etnik Madura dan berbahasa ibu BM. Faktor yang mendukung lainnya adalah LT yang berada di lingkungan keluarga dan ST serta TT.

b. Pilihan BJ; faktor utama yang mempengaruhi pemakaian $\mathrm{BJ}$ tersebut adalah PK karena dalam tuturan tersebut banyak melibatkan PK yang berasal dari luar etnik Madura dan sebagain besar berasal dari etnik Jawa. Selain itu, BJ merupakan bahasa sehari-hari di Kota Surakarta.

c. Pilihan BI; faktor utama yang mempengaruhi pemakaian $\mathrm{BI}$ tersebut adalah PK yang heterogen, bisa berasal dari etnik Madura, Jawa, atau lainnya dan didukung oleh ST yang formal atau resmi. Pemakaiannya memiliki frekuensi yang tinggi di ranah pendidikan.

d. Pilihan BC; faktor utama yang mempengaruhi pemakaian $\mathrm{BC}$ ini adalah $\mathrm{PK}$ yang heterogen yang didukung ST yang informal.

(2) Fungsi pilihan bahasa MEMS dalam penelitian ini dapat diuraikan sebagai berikut.

a. Fungsi pilihan BM yaitu makna kekeluargaan, ke- 
akraban, ungkapan perasaan, menjaga kerahasiaan, identitas etnik, dan pemertahanan budaya.

b. Fungsi pilihan BJ yaitu komunikasi dengan masyarakat, kebiasaan, adaptasi, dan keakraban.

c. Fungsi pilihan BI yaitu situasi formal atau resmi, komunikasi antaretnik, sekadar bergengsi, pendidikan, dan pertemuan awal.

d. Fungsi pilihan $\mathrm{BC}$ yaitu situasi yang nonformal, penegasan pesan, dan konsep baru.

(3) Kekhasan pemakaian bahasa MEMS di ranah pendidikan yaitu meliputi berbagai aspek yaitu (1) kata sapaan BM yang masih dipertahankan seperti kata kakak, sampenyan, dan bug, khususnya di lingkungan keluarga, (2) Pemakaian partikel yang selalu muncul dalam tuturan, seperti $l e$, bik dari BM dan $t a, m b o k$ dari BJ, (3) Bentuk perulangan yang sering muncul dalam tuturan seperti teh ngateh, nak kanak, dan lain-lain yang pemben-tukannya sama dengan boh aboh, (4) Bentuk kata yang mempunyai variasi dan sering muncul dalam tuturan yaitu iyeh, iyut, yut, yeh yang berarti iya, (5) ragam BM biasa dan BJ ngoko adalah ragam bahasa yang selalu muncul dalam tuturan MEMS. BM halus atau BJ krama muncul jika memang Mt-nya. adalah seorang yang sangat dihormati, seperti kiai, dan (6) dialek Bangkalan adalah dialek BM yang paling dominan dipakai oleh MEMS karena sebagian besar masyarakat Madura yang ada di Surakarta berasal dari Madura bagian barat.

\subsection{Saran}

Pilihan bahasa yang terjadi pada MEMS pada ranah pendidikan didominasi oleh $\mathrm{BI}$. Hal ini mengingat di ranah pendidikan sebagian besar ST yang ada adalah formal atau resmi. Untuk lebih mempertajam kajian pemakaian bahasa MEMS disarankan melihat dari berbagai aspek disiplin ilmu. Dengan adanya kajian mengenai pemakaian bahasa masyarakat etnik Madura di Surakarta ini diharapkan akan membantu bidang ilmu yang lain -misalnya, sosiologi, antropologi atau komunikasi- untuk dijadikan informasi bagi penelitiannya. Pilihan bahasa yang lain juga harus dipertajam analisisnya sehingga dapat memberikan pemahaman yang komprehensif mengenai 
pemakaian $\mathrm{BM}, \mathrm{BJ}, \mathrm{BI}$, dan $\mathrm{BC}$ yang dilakukan oleh MEMS.

Fungsi pilihan bahasa MEMS juga bervariasi dan berhubungan dengan konteks. Fungsi pilihan BM, $\mathrm{BJ}, \mathrm{BI}$, dan BC dapat dikaji melalui berbagai sudut pandang; dari penutur, mitra tutur, dan dari fenomena kebahasaan yang dipahami oleh peneliti. Sebagai masyarakat pendatang, MEMS harus lebih memperhatikan pemakaian bahasa menurut fungsinya. Misalnya $\mathrm{BJ}$ yang digunakan juga harus memperhatikan tingkat tutur yang ada dalam masyarakat Jawa pada umumnya dan Kota Surakarta pada khususnya.
Kurang pahamnya MEMS memahami budaya Jawa akan memunculkan kekhasan dalam pemakaian bahasanya, baik dalam BM, BJ, maupun BI. Agar lebih dapat menggunakan bahasa sesuai dengan kondisi dan situasi, MEMS harus lebih memahami dan menggunakan pilihan bahasanya sesuai dengan konteks. Kekhas pemakaian bahasa MEMS sebagian besar dapat dikategorikan sebagai penyimpangan dalam bahasa, baik dalam BM, BI, maupun BI. Oleh karena itu pemakain bahasa yang bersifat merusak atau menyimpang dari kiadah seharusnya dihindari pemakaiannya.

\section{Pustaka Acuan}

Alwasilah, Chaedar. 1989. Sosiologi Bahasa. Bandung : Angkasa. Crystal, David. 1993. The Cambridge Ensyclopedia of Language. Cambridge: Cambridge Unversity Press.

Dwiraharjo, Maryono. 2001. Bahasa Jawa Krama. Surakarta: Pustaka Cakra Surakarta.

Fasold, Ralph. 1993. The Sociolinguistics of Society. New York: Basil Blackwell. Gal, Susan. 1979. Language Shift: Social Determinats of Linguistic Change in Bilingual Austria. New York: Academic Press.

Giles, Howard. 1979. Language and Social Psychology. Oxford: Basil Blackwell Publisher.

Hodge, Robert and Guther Kuess. 1991. Social Semiotics. Cambridge: Polity Press.

Biro Pusat Statistik (BPS) Kota Surakarta. 2002. Surakarta dalam Angka 2002. Surakarta.

Markhamah. 2000. Etnik Cina: Kajian Linguistis Kultural. Surakarta: Uni- 
versitas Muhammadiyah Surakarta Press.

Pelly, Usman. 1994. Interaksi Antar Suku Bangsa dalam Masyarakat Majemuk. Jakarta: Departemen Pendidikan dan Kebudayaan.

Romaine, Suzanne, 1995. Bilingualism. Massachusette: Blackwell.

Saddhono, Kundharu. 2004. "Bahasa Etnik Madura di Surakarta: Sebuah Kajian

Sosiolinguistik". Surakarta: Tesis Prograam Studi Linguistik Deskriptif

Pascasarjana Universitas Sebelas Maret.

Sajid, RM. 1984. Babad Sala (Transkrip). Perpustakaan Reksa Pustaka,

Mangkunegaran Surakarta.

Sumarsono. 1993. Pemertahanan Bahasa Melayu Loloan di Bali. Jakarta:

Departemen Pendidikan dan Kebudayaan.

Sudaryanto. 1995. Linguistik: Identitasnya, Cara Penanganan Obyeknya,

dan Hasil Kajiannya. Yoyakarta: Duta Wacana University Press.

Sutirto, Tundjung W.. 2000. Perwujudan Kesukubangsaan Kelompok Etnik

Pendatang. Surakarta: Pustaka Cakra Surakarta.

Sutopo, H. B. 1996. Metodologi Penelitian Kualitatif: Metodologi Penelitian untuk Ilmu-ilmu Sosial dan Budaya. Surakarta: Universitas Sebelas Maret Surakarta.

Suwito. 1997. Sosiolinguistik. Surakarta: Fakultas Sastra Universitas Sebelas Maret.

Tohir, Ahmad. 2002. Wawancara

Tohir, Amir. 2002. Wawancara

Uhlenbeck, E.M. 1964. A Critical Survey of Studies on The Languages of Java and Madura. Netherlands: 's Gravenhage Martinus Nijhoff.

Wiyata, Latief. 2001. "Memahami Budaya Perilaku Orang Madura: Pelajaran Kasus Sampit". Jakarta: Kompas Edisi 6 April 2001. . 2002. Carok: Konflik Kekerasan dan Harga Diri Orang Madura. Yogyakarta: LKiS.

Wierzbicka, Anna. 1996. Cross-Cultural Communication. Melbourne: The Third Austalian Linguistic Institute. 